\title{
Geochemistry of surface sediments in parts of Bandipora-Ganderbal areas, Kashmir valley, western Himalaya: Implications for provenance and weathering
}

\author{
Ishfaq Ahmad Mir ${ }^{1, *}$ and Riyaz Ahmad Mir ${ }^{2}$ \\ ${ }^{1}$ State Unit: Karnataka and Goa, Southern Region, Geological Survey of India, Bengaluru 560 111, India. \\ ${ }^{2}$ State Unit: Jammu and Kashmir, Northern Region, Geological Survey of India, Srinagar 190 008, India. \\ *Corresponding author. e-mail: geoishfaq@gmail.com
}

MS received 1 June 2018; revised 10 May 2019; accepted 13 June 2019

Sediment geochemistry is an important tool to understand the sediment provenance and weathering. The present study describes the geochemical distribution, the provenance and the degree of weathering in surface sediments in parts of Bandipora-Ganderbal areas, Kashmir valley, western Himalaya. Following the standard operating procedure of the Geological Survey of India, high-density sediment sampling over an area of $800 \mathrm{~km}^{2}$ of toposheet Nos. 43J/11 and 43J/12 (part) was carried during the Field Season Programme of 2014-2015. A total of 200 stream and slope wash sediment samples collected on a $2 \times 2$ grid pattern, covering an area of $800 \mathrm{~km}^{2}$ and 10 numbers of duplicate samples were used in this study. An analysis of major and trace element concentrations of the sediment samples revealed significant changes corresponding to different geological formations of the area. The correlation matrix of $\mathrm{SiO}_{2}, \mathrm{Al}_{2} \mathrm{O}_{3}, \mathrm{TiO}_{2}$, $\mathrm{Fe}_{2} \mathrm{O}_{3}, \mathrm{MnO}, \mathrm{K}_{2} \mathrm{O}$, Th and $\mathrm{Y}$ showed a positive correlation with each other and negative correlation with $\mathrm{CaO}, \mathrm{MgO}$ and $\mathrm{Sr}$, thereby indicating two dominant geological provenances of the sediments. Two dominant geochemical patterns revealed provenances from basaltic and carbonate rock formations in the area. Furthermore, an analysis of geochemical weathering indices (chemical index of alteration and chemical index of weathering) revealed a poor (27) to moderate (78) degree of weathering in this area. This observation is further substantiated by the immaturity of the soil sediments in the area.

Keywords. Stream sediment; slope wash; provenance; chemical weathering; Kashmir; Himalaya.

\section{Introduction}

Stream and slope wash (SSW) sediments are the commonly used sampling media for the regional geochemical surveys (Cohen et al. 1999) because these sediments represent the source catchment area of the stream drainage network (Ranasinghe et al. 2008). Nevertheless, the phenomenon of natural homogenisation of these fine-grained sediments produces a better representative sample of the average composition of the provenance (McLennan et al. 1993; Fralick and Kronberg 1997;
Weltje and von Eynatten 2004). Chemical and mineralogical compositions of sediments are useful in understanding the geochemical cycling of elements, erosional characteristics of river basin (Martin and Meybeck 1979) and the weathering and erosional processes in the source areas. It is notable that the erosion of the rocks depends on the geology of the region, topographic setting and climate (Nesbitt 1979; Das et al. 2005; Tripathi et al. 2007; Rajamani et al. 2009). Thus, the geochemistry and mineralogy of SSW sediments commonly explain the composition of source rocks, 
weathering history, hydrological processes and climate of the area (Pratt and Lottermoser 2007; Grunsky et al. 2009).

The study of SSW sediment geochemistry is also used for the identification of the impact of the anthropogenic activities such as the mining, agriculture, industry and settlement activities (Sharma and Rajamani 2001; Piper et al. 2006). The soil can thus be a direct pathway for potentially toxic chemicals of natural or anthropogenic origin to enter the human body (Oliver 1997). Surface sediment or soil is a critical natural resource that plays a key role in determining human health and ecosystem integrity. Therefore, the assessment of the chemical characteristics of the soil is very essential for the better assessment and monitoring of the risks that can affect humans and other biotic ecosystems with regard to decision-making and fostering more integrated environmental regulation.

Geochemical surveys and mapping were initially carried for mineral exploration (Garrett et al. 2008). The geochemical maps thus produced can also be used as references to measure spatial and temporal changes in the geochemistry of the natural environment (Darnley et al. 1995) and to better understand the factors that control the geochemical variations of the sediments (Reimann and Garrett 2005). The areal coverage of the existing geochemical maps ranges from regional to continental scales (Xie and Cheng 1997) such as the geochemical atlases of Europe, Australia, China and North America, etc. (Salminen et al. 2005; De Vos and Tarvainen 2006; Wang et al. 2007; Smith 2009). Therefore, at these low densities, the underlying geology and regional climatic characteristics tend to dominate regional geochemical patterns and the features related to anthropogenic effects are difficult to segregate.

A major application of geochemical surveys is the large-scale geochemical mapping for a variety of scientific and societal purposes (Johnson et al. 2005). It is primarily used for environmental purposes including the separation of natural sources of metals from anthropogenic and organics, evaluation of soils for agricultural purposes, environmental management, medical geochemistry and land-use classification (Tan 1989). The geochemical surveys not only yield data of economic significance but also provide much information of fundamental interest. However, it is important to mention that the SSW sediment sampling is preferred to hard rock sampling on the pretext that the latter represents a relatively small area close to the sample site.

In the same line, the Geological Survey of India (GSI) has commenced a country-wide geochemical mapping programme, i.e., the National Geochemical Mapping Programme (NGCM) since 2001. Furthermore, the GSI has prioritised the geochemical mapping in its 'vision 2020 document' to identify new prospective areas of mineral deposits and demarcated areas of potential geo-environmental health hazards in this programme. The NGCM programme envisages the geochemical mapping of the entire country on a systematic grid pattern for generating a multi-elemental database and identifying geochemical anomalies for varied applications such as to study the behaviour, concentration and dispersion pattern of various elements for its application in mineral exploration, agriculture and human/animal health environment.

In the Kashmir basin (KB), previously only a limited number of geochemical studies of sediments have been carried. For instance, Kapoor (1963) carried out geochemical studies of Lidder stream sediments, whereas Rashid et al. (2013) studied geochemistry of the Wular Lake sediments. Bhat and Bhat (2014) carried out geochemical studies of the south-western areas of Pulwama district. Similarly Mir and Jeelani (2015) studied the geochemical characteristics of the bottom sediments of the river Jhelum. The sediments of the Manasbal and Wular lakes falling within the study area have been studied recently (Rashid et al. 2015). Babeesh et al. (2017) carried out a geochemical study of the Manasbal lake sediments to understand weathering, provenance and the tectonic setting of the catchment area. Shah et al. (2017) studied the spatial distribution of diatoms and the physicochemical characteristics of the Wular lake sediments.

Considering these facts in view, the present study has been carried out under the NGCM programme during its Field Season Programme (FSP) of 2014-2015. The present study has been carried out in parts of the Bandipora-Ganderbal districts of the $\mathrm{KB}$ and involves a high-density SSW sediment sampling for multi-element geochemical mapping. The specific objectives of the study are to:

- Understand the spatial distribution of elements.

- Understand the geochemical provenance of the sediments.

- Understand the degree of weathering of the source rock material. 


\section{Study area}

The KB is situated towards the north of India. It is a boat-shaped elongated basin lying between the greater Himalayan range in the northeastern side and the Pir Panjal range in the southwestern side. The KB has a general trend in the NW-SE direction and is $\sim 135 \mathrm{~km}$ long and $32 \mathrm{~km}$ wide with an area of about $15,948 \mathrm{~km}^{2}$. The elevation of the $\mathrm{KB}$ varies from $\sim 1500$ to $4000 \mathrm{~m}$ asl with an average elevation of $1620 \mathrm{~m}$ asl. Geologically speaking, the KB is a thrust-bounded basin and is described as the 'Kashmir Nappe zone' comprising the marine sedimentary rocks of the Palaeozoic-Mesozoic with a Pre-Cambrian basement thrusted along a regional tectonic plane, namely, the Panjal thrust over the younger rocks of the autochthones (Wadia 1931). The KB possesses almost a complete stratigraphic record of rocks of all ages ranging from the Archaean to Recent (Dar et al. 2013; Mir et al. 2016).

The present study area covers parts of the Bandipora-Ganderbal districts located towards the north-east of the KB. The study area lies between $34^{\circ} 10^{\prime}-34^{\circ} 30^{\prime} \mathrm{N}$ latitudes and $74^{\circ} 30^{\prime}-74^{\circ} 45^{\prime} \mathrm{E}$ longitudes. The study area covers an area of about $800 \mathrm{~km}^{2}$ falling within the toposheet number of 43J/11 (full) and 43J/12 (northern part) as shown in figure 1 . The study area has been selected as per the SOP of the GSI under its FSP of 2014-2015 (SOP 2014). The landscape of the study area consists mainly of flat areas with lower elevations and highly rugged and mountainous hilly areas. The northern and northeastern parts of the study area ascend to a height of $\sim 5142 \mathrm{~m}$ asl around the Harmukh mountain peak whereas the western and south-western parts drop to an elevation of $\sim 1550$ $\mathrm{m}$ asl, particularly around the outlet of the Wular Lake near the Ningli stream, Sopore (figure 1). The Jhelum river and its major tributaries such as the Sindh, Ajas-kul, Erin, Madhumati, Ashtung-kul, Kunis-nal, Zaingare-kul and Ningli form the major drainage network of the study area. Additionally, the study area is characterised by many water bodies and wetlands. For example, the Wular and Manasbal are the major lakes, whereas the Haigam jil, Takia, Tulmul and Naugam are the major wetlands of the area (figure 1).

\subsection{Geology of the area}

The study area is covered on its extreme northern side by the Pohru group of rock formations which include the limestone, siltstone, shale and arenite of the Cambrian-Silurian and agglomeratic slates of the Upper Carboniferous age (Singh 1982; Razdan and Raina 1986; Thakur and Rawat 1992). The Panjal volcanics and Triassic limestone formations are exposed in the northeastern and north-western sides, whereas the Quaternary Karewa deposits and recent alluvium are present in its south-eastern, southern and southwestern sides (Sarah et al. 2011). Panjal volcanics are of the Permian age and consist mainly of distinctly layered andesitic to basaltic lava flows of dark grey to green colour, which are at places porphyritic and amygdaloidal in nature. Triassic limestone consists of a thick sequence of compact blue limestone, slates and dolomites which at places contain cephalopods, gastropods, bivalves and other marine microfossils (Wadia 1931). It is important to mention that the volcanic basalts and limestone rocks are locally mined as a building stone and road construction material. The low-lying area is filled with sediments of the Karewa group and recent alluvium (De Terra and Paterson 1939; Bhatt and Chatterji 1976). Karewa are the fluvio-glacio-lacustrine deposits of the Plio-Pleistocene period and are composed of fine silty clays with sand and boulder gravel conglomerates and embedded moraines (Wadia 1931; Burbank and Johnson 1982; Singh 1982; Agarwal and Agarwal 2005). The recent alluvium is made up of fine particles of silt and clay and coarser particles of sand and gravel. The detailed geological map modified after Thakur and Rawat (1992) of the study area is shown in figure 2 .

\subsection{Climate of the area}

In general, the KB has a temperate climate largely controlled by its geographic location within the western Himalayan mountain ranges. The climate of $\mathrm{KB}$ falls under the sub-Mediterranean type with four distinct seasons classified based on mean temperature and precipitation of the area (Mir and Jeelani 2015). The climate of the KB is broadly described as hot in summer, cold in winter and mild in spring and autumn seasons. Weather is often cooler in the hilly areas compared to the lowlying area. Summer is usually hot and dry, but relative humidity is generally high and the nights are pleasant. The hottest month is July with an average temperature of $32^{\circ} \mathrm{C}$ and the coldest months are December-January with a minimum 


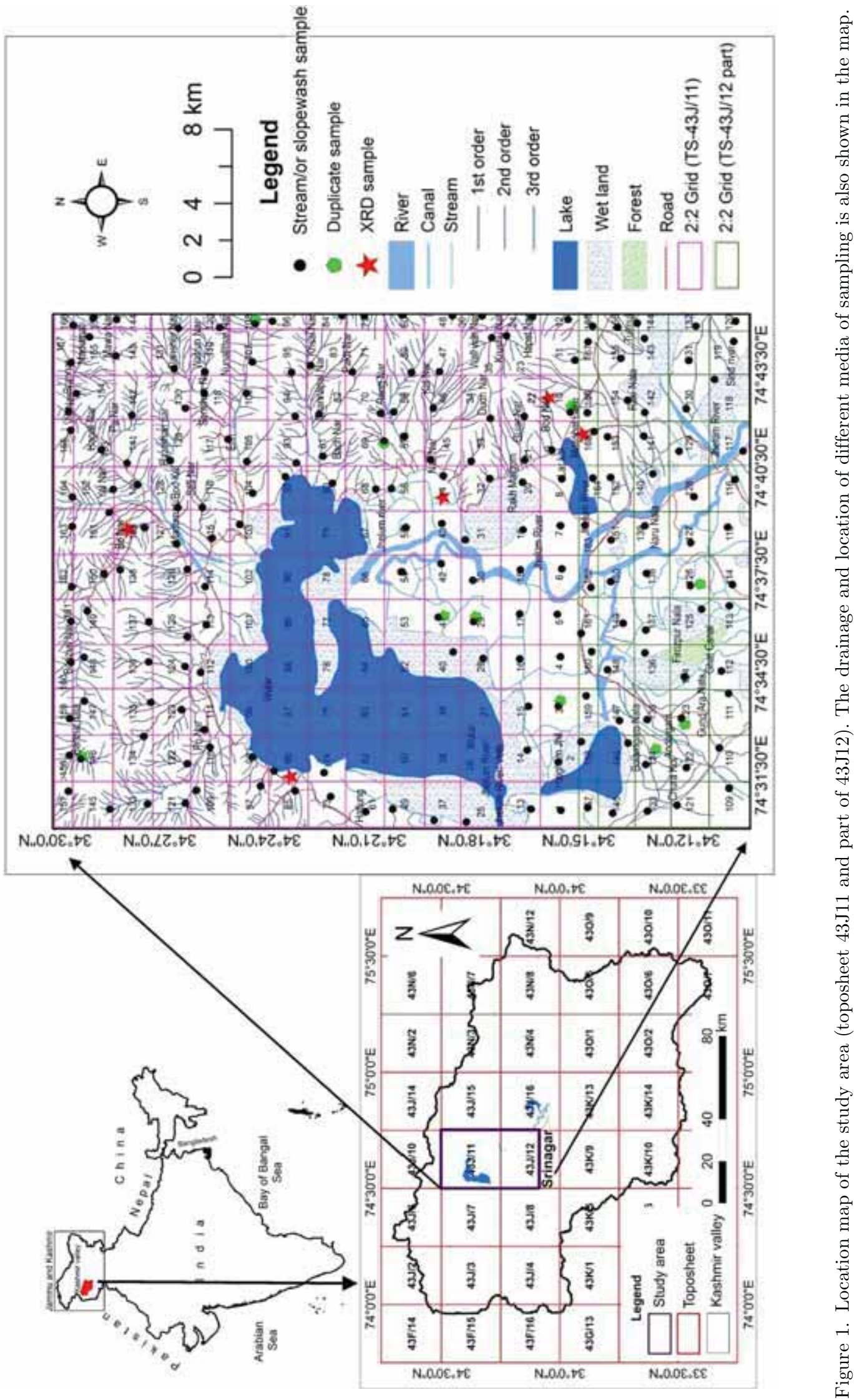



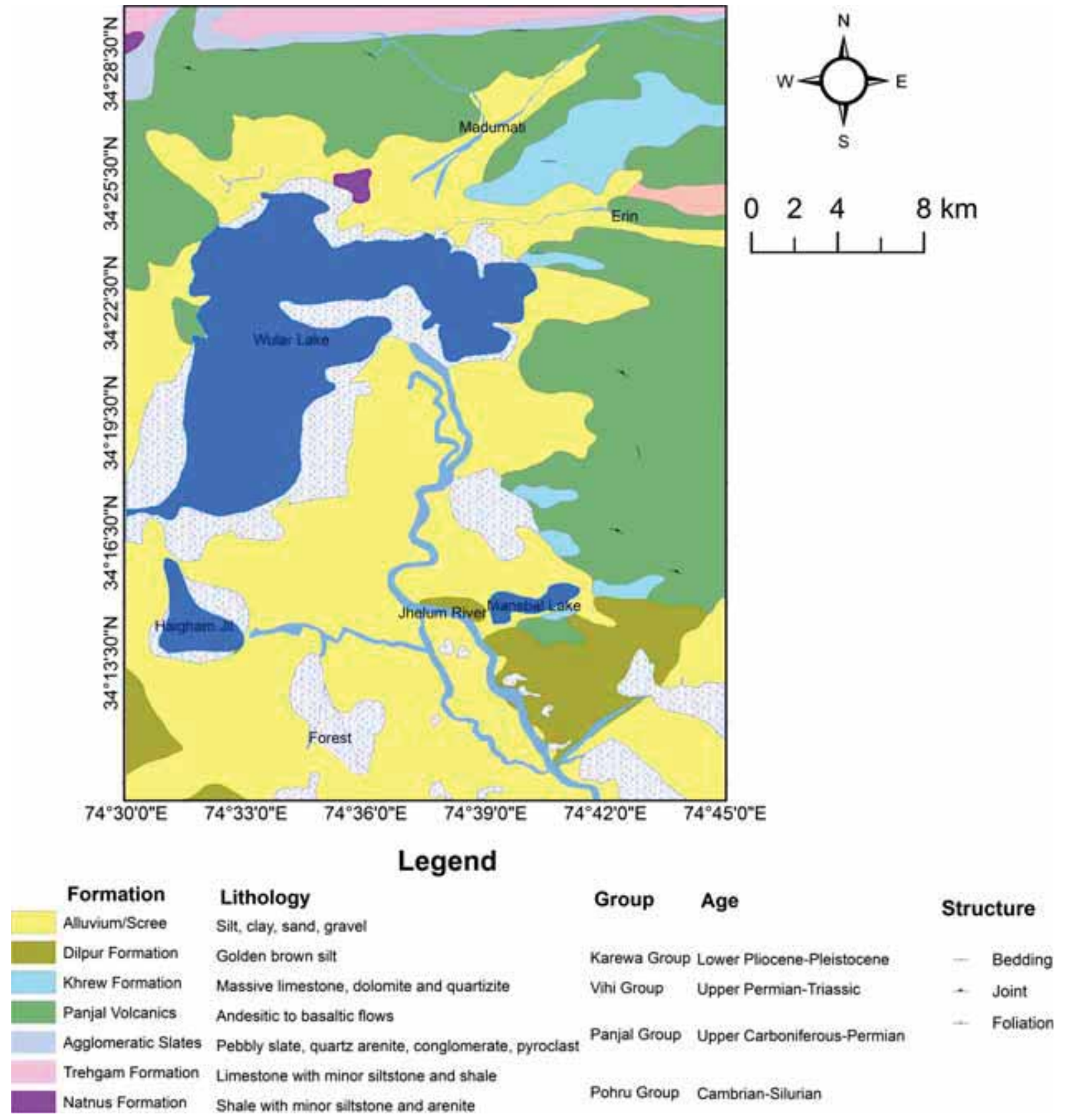

Figure 2. Geological map of the study area (modified after Thakur and Rawat 1992).

temperature of $-15^{\circ} \mathrm{C}$. Precipitation occurs throughout the year and no month is particularly dry. Precipitation in winter months usually falls in the form of snow. In winters, precipitation occurs from the western disturbances originating from the Mediterranean Sea (Mir 2018). KB receives an average rainfall of $710 \mathrm{~mm}$ per year. On average, there are 103 days per year with more than $0.1 \mathrm{~mm}$ rainfall. March is the wettest month with an average rainfall of $121 \mathrm{~mm}$ and September-November are the driest months with an average rainfall of $28 \mathrm{~mm}$ (Mir and Jeelani 2015).

\section{Material and methods}

\subsection{Sample collection and processing}

The sampling was undertaken following the NGCM guidelines as per the standard operating procedure (SOP 2014) of GSI. Before the actual execution of the sample collection, a number of prefield preparations were carried out during which the various thematic maps, especially the drainage map (1:50,000 scale) of the study area have been generated. Furthermore, a number of tools such as 
hand scoops, polythene covers and weighing machine, 120 mesh size sieves, wooden pestles for powdering lumps and food grade/PET bottles of 500 and $250 \mathrm{~g}$ capacity, etc., were also procured in advance during prefield exercises.

The drainage map is a very essential tool for planning and executing the high-density SSW sediment sampling on the defined grid pattern of $2 \times 2 \mathrm{~km}$ as per the SOP (2014). For the purpose of $2 \times 2$ gridding of the toposheets used as base maps for sampling, Map INR has been used. The drainage network of the study area has been derived from the freely advanced space-borne thermal emission and reflection radiometer-global digital elevation model (ASTER GDEM) in the geographic information platform. The DEM was downloaded from the USGS website https://earthexplorer.usgs.gov/. After the preparation of drainage and grid maps, tentative sampling points were generated for the collection of the planned SSW samples generally from the first-, second- or third-order streams covering the major part of the targeted grid and to represent a wide catchment area. For precise and accurate sampling, the coordinates of each tentative point were noted and fed into the hand-held GPS. However, during the execution of the actual sample collection, these coordinates were used to navigate to reach and access the sampling locations.

The fine-to-medium grained bed load (silt/clay/ sand) sediments transported and deposited by running water were collected over a distance of $100 \mathrm{~m}$ at $1-3$ places of upstream sites close to the cell margin at the outlet of the stream (figure 1). The coarse pebbles and cobbles, if present, were removed at the site before actual sample collection. However, if the grids were devoid of any streams, slope wash samples were collected based as per the local slope/or slope map derived from the DEM. At each sampling site, actual coordinates as well as other field-related information such as lithology, land-use land cover, sample material type and other details were recorded. About $5 \mathrm{~kg}$ of the sediment sample were collected in polyethylene bags of $10 \mathrm{~kg}$ capacity followed by consistent labelling and brought to field camp for further processing. A total of $200 \mathrm{SSW}$ samples along with 10 duplicate/repeat samples for cross-check analysis were collected from the area. In addition, a total of five samples selected randomly in the area were also collected for mineralogical studies. At the field camp, the samples were air dried, deplumed, powdered and sieved to a 120 micron mesh size using specially made wooden tools and recommended metallic sieves (SOP 2014). This process is helpful in avoiding metal and other contamination. It is generally accepted that finegrained sediment particles (silt and clay with a particle size of $120 \mu \mathrm{m}$ ) exhibit properties suitable for chemical sorption than the coarse particles. The samples were then coned, quartered and stored in food-grade bottles and made into two sets each of 500 g quantity. One set was submitted to GSI, Chemical Laboratory, Lucknow for chemical analysis, whereas the other set has been stored in a sample repository maintained at GSI, Jammu.

\subsection{Chemical analysis of samples}

In this study, the major oxides and trace elements were analysed using X-ray fluorescence (XRF) (make and model: M/S Panalytical; MAGIX, $2.4 \mathrm{KW}$ sequential XRF spectrometer). For this process, about $5.0 \pm 0.01 \mathrm{~g}$ of each powdered sample was spread in an aluminium cup $(40 \mathrm{~mm}$ diameter in size) over boric acid powder (AR Grade) and pressed into a pellet under a pressure of $20 \mathrm{t}$ with the help of a hydraulic press pellet machine to get a uniformly pressed pellet. The sample pellet was kept in the sample cup of the $\mathrm{XRF}$ unit for the major and trace element analyses. The XRF instrument was controlled from an external computer, running an analytical software package (SuperQ). The detection limit was $0.1 \%$ for major elements and $1.00 \mathrm{mg} / \mathrm{l}$ for trace elements. The standard reference material GSD10 with known element concentrations was analysed after each batch of 20 samples for accuracy and duplicate samples after each batch of 10 samples was analysed for repeatability. The accuracy of the measurement is $\pm 3 \%$ and precision is $\pm 5 \%$.

For mineralogical studies, the dried samples were ground to approximately $<200$ mesh size in an agate mill to achieve a grain size of about $5-10 \mu \mathrm{m}$. Mineralogical analysis was performed using an X'Pert PRO X-ray diffraction ${ }^{\mathrm{TM}}$ (XRD), PAN analytical instrument with automatic computer control. The samples were X-rayed for the identication of mineral composition and the diffractograms were processed using MUSE software of Perkin Elmer.

After the chemical analysis, the data were processed in Excel and the statistical analysis was carried out using STATISTICAv.6. The elemental distribution maps were generated using ArcGIS 10.1 and Surfer 12 software. 


\section{Results}

The statistical results, i.e., the minimum, maximum and mean values of major oxides and trace elements of the surface sediments of the Bandipora-Ganderbal areas and their comparison with Post Archaean Australian Shale (PAAS) (Taylor and McLennan 1985), North American Shale Composition (NASC) (Gromet et al. 1984) and Upper Continental Crust (UCC) (Wedepohl 1995) are given in table 1 . The results indicated that $\mathrm{SiO}_{2}$ is the dominant oxide and its concentration varied from 30.58 to $67.73 \mathrm{wt} \%$ with an average value of $58.7 \mathrm{wt} \% . \mathrm{SiO}_{2}$ is followed by a relatively higher concentration of $\mathrm{Al}_{2} \mathrm{O}_{3}$ in comparison with the other major oxides. The concentration of $\mathrm{Al}_{2} \mathrm{O}_{3}$ varied from 9.23 to $16.89 \mathrm{wt} \%$ with an average value of $13.4 \mathrm{wt} \%$, whereas the concentration of $\mathrm{Fe}_{2} \mathrm{O}_{3}$ varied from 4.03 to 9.96 wt $\%$ with an average value of $5.7 \mathrm{wt} \% . \mathrm{MgO}$ and $\mathrm{K}_{2} \mathrm{O}$ indicated an average concentration of 2.4 to 2.5 wt $\%$ each. $\mathrm{TiO}_{2}, \mathrm{CaO}$ and $\mathrm{MnO}$ indicated a concentration of less than $1 \mathrm{wt} \%$. Among the trace elements, Sr indicated a higher concentration that varied from 40 to $559 \mathrm{ppm}$ with an average value of $148 \mathrm{ppm}$. The concentration of Th varied from 4 to $16 \mathrm{ppm}$ with a mean value of $11.10 \mathrm{ppm}$, whereas the concentration of $\mathrm{Y}$ varied from 17 to $40 \mathrm{ppm}$ with an average of $29.9 \mathrm{ppm}$, respectively. Overall, the order of concentration of major oxides followed a trend as $\mathrm{SiO}_{2}>\mathrm{Al}_{2} \mathrm{O}_{3}>\mathrm{Fe}_{2} \mathrm{O}_{3}>-$ $\mathrm{CaO}>\mathrm{MgO}>\mathrm{K}_{2} \mathrm{O}>\mathrm{TiO}_{2}>\mathrm{MnO}$, whereas in the case of trace elements, the order of concentration is observed as $\mathrm{Sr}>\mathrm{Th}>\mathrm{Y}$. In comparison with the average UCC, PAAS and NASC, the average values of almost all oxides and elements are lower and depleted except for $\mathrm{CaO}$ which showed higher average values than NASC and UCC. The MgO revealed almost similar average values compared to the world standards.

An analysis of the spatial distribution of both major oxides and trace elements revealed both similar, that is dominant among the elements, and dissimilar distribution patterns. For instance, the first group of elements that include $\mathrm{SiO}_{2}, \mathrm{Al}_{2} \mathrm{O}_{3}$, $\mathrm{Fe}_{2} \mathrm{O}_{3}, \mathrm{TiO}_{2}, \mathrm{MnO}, \mathrm{K}_{2} \mathrm{O}$, Th and $\mathrm{Y}$ acted as a coherent group and indicated a similar distribution pattern. Overall, this group revealed the lowest values towards the north-southeastern areas of the area. Similarly, the second group of elements including $\mathrm{CaO}, \mathrm{MgO}$ and $\mathrm{Sr}$ also revealed a similar distribution pattern. This group, however, indicated the highest concentration in narrow areas towards the south-eastern part of the study area. The distribution pattern of the second group of elements is in contrast to the distribution pattern of the first group of elements. However, it is important to note that the distributional pattern of both these elemental groups correlates positively with the local lithology of the area. The spatial distribution of major oxides and trace elements is shown in figure 3. Moreover, to substantiate the chemical analysis of the sediments, a mineralogical analysis of five sediment samples collected randomly from the area was also carried out. To report the mineralogical results in this study, the procedure and classification of minerals as proposed in the SOP (2014) of the GSI has been followed. The results of the mineralogical studies are given in table 2 .

Table 1. Statistical analysis of major oxides (wt\%) and trace elements (ppm) of the study area and its comparison with PAAS Taylor and McLennan (1985), NASC) Gromet et al. (1984) and UCC Wedepohl (1995).

\begin{tabular}{|c|c|c|c|c|c|c|}
\hline \multirow[b]{2}{*}{ Oxide/element } & \multicolumn{3}{|c|}{ Present study } & \multirow[b]{2}{*}{ PAAS } & \multirow[b]{2}{*}{ NASC } & \multirow[b]{2}{*}{$\mathrm{UCC}$} \\
\hline & Minimum & Maximum & Average & & & \\
\hline $\mathrm{SiO}_{2}(\mathrm{wt} \%)$ & 30.58 & 67.73 & 58.7 & 62.80 & 64.80 & 60.2 \\
\hline $\mathrm{Al}_{2} \mathrm{O}_{3}(\mathrm{wt} \%)$ & 9.23 & 16.89 & 13.4 & 18.90 & 16.90 & 15.27 \\
\hline $\mathrm{Fe}_{2} \mathrm{O}_{3}(\mathrm{wt} \%)$ & 4.03 & 9.96 & 5.8 & 7.23 & 6.33 & 7.26 \\
\hline $\mathrm{CaO}(\mathrm{wt} \%)$ & 0.74 & 24.11 & 4.2 & 1.30 & 3.56 & 5.45 \\
\hline $\mathrm{MgO}(\mathrm{wt} \%)$ & 1.60 & 6.71 & 2.5 & 2.20 & 2.85 & 4.59 \\
\hline $\mathrm{K}_{2} \mathrm{O}(\mathrm{wt} \%)$ & 1.11 & 4.15 & 2.4 & 3.70 & 3.99 & 2.99 \\
\hline $\mathrm{MnO}(\mathrm{wt} \%)$ & 0.04 & 0.29 & 0.1 & 0.11 & 0.06 & 0.10 \\
\hline $\mathrm{TiO}_{2}(\mathrm{wt} \%)$ & 0.33 & 1.64 & 0.8 & 1.00 & 0.78 & 0.57 \\
\hline Sr (ppm) & 40 & 559 & 148 & 200 & 142 & 320 \\
\hline Th (ppm) & 4.00 & 16.00 & 11.1 & 14.60 & 12.00 & 14.00 \\
\hline $\mathrm{Y}(\mathrm{ppm})$ & 17.00 & 40.00 & 29.9 & 27.00 & 35.00 & 21 \\
\hline
\end{tabular}



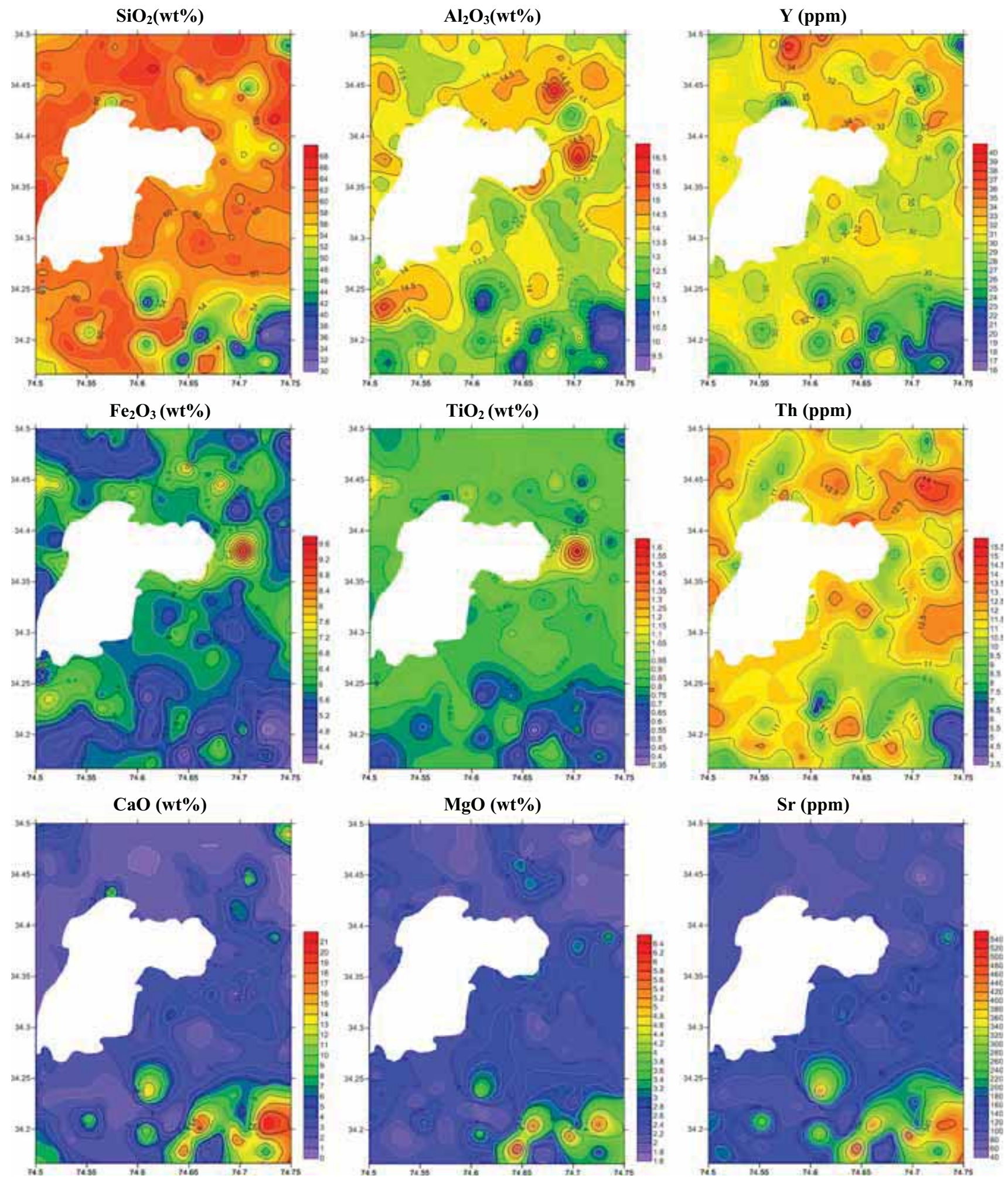

Figure 3. Distribution pattern of major oxides (wt\%) and trace elements (ppm) of sediments of the study area.

\section{Discussion}

\subsection{Element distribution and provenance}

In this study, an analysis of the geochemical elements of the sediments in comparison with the crustal averages such as PAAS (Taylor and McLennan 1985), NASC (Gromet et al. 1984) and UCC (Wedepohl 1995) revealed that there are a significant number of samples having a concentration of the given world average. For instance, about $25.5 \%$ of samples have $\mathrm{SiO}_{2}$ higher than the 
Table 2. XRD results of the mineralogy of stream sediment constituents detected in the semi-quantitative analysis of the crystalline portion of sediment samples by RIR values.

\begin{tabular}{llll}
\hline & \multicolumn{2}{c}{ Number and \% of samples enriched } \\
\cline { 2 - 4 } Element/oxide & \multicolumn{1}{c}{$>$ PAAS } & \multicolumn{1}{c}{$>$ NASC } & \multicolumn{1}{c}{$>$ UCC } \\
\hline $\mathrm{SiO}_{2}($ wt\%) & $51(25.5 \%)$ & $14(7 \%)$ & $106(53 \%)$ \\
$\mathrm{Al}_{2} \mathrm{O}_{3}(\mathrm{wt} \%)$ & $0(0 \%)$ & $1(0.5 \%)$ & $5(2.5 \%)$ \\
$\mathrm{Fe}_{2} \mathrm{O}_{3}(\mathrm{wt} \%)$ & $9(4.5 \%)$ & $34(17 \%)$ & $9(4.5 \%)$ \\
$\mathrm{CaO}(\mathrm{wt} \%)$ & $171(85.5 \%)$ & $71(35.5 \%)$ & $41(20.5 \%)$ \\
$\mathrm{MgO}(\mathrm{wt} \%)$ & $128(64 \%)$ & $26(13 \%)$ & $4(2 \%)$ \\
$\mathrm{K}_{2} \mathrm{O}(\mathrm{wt} \%)$ & $3(1.5 \%)$ & $1(0.5 \%)$ & $7(3.5 \%)$ \\
$\mathrm{MnO}(\mathrm{wt} \%)$ & $6(3 \%)$ & $0(0 \%)$ & $6(3 \%)$ \\
$\mathrm{TiO}(\mathrm{wt} \%)$ & $9(4.5 \%)$ & $167(83.5 \%)$ & $193(96.5 \%)$ \\
$\mathrm{Sr}(\mathrm{ppm})$ & $22(11 \%)$ & $67(33.5 \%)$ & $10(5 \%)$ \\
$\mathrm{Th}(\mathrm{ppm})$ & $1(0.5 \%)$ & $43(21.5 \%)$ & $2(1 \%)$ \\
$\mathrm{Y}(\mathrm{ppm})$ & $167(83.5 \%)$ & $3(1.5 \%)$ & $8(4 \%)$ \\
\hline
\end{tabular}

PAAS values, whereas there are about $53 \%$ of samples having higher values than UCC. Similarly, there are about $34 \%$ of samples having higher values of $\mathrm{Fe}_{2} \mathrm{O}_{3}$ than the NASC. However, it is very prominent that in the case of $\mathrm{CaO}$, there are about $85.5 \%, 35.5 \%$ and $20.5 \%$ of samples having higher concentration than PAAS, NASC and UCC. Similarly, MgO values are higher in $64 \%$ of samples than PAAS, whereas, $83.5 \%$ and $96.5 \%$ samples have higher values of $\mathrm{TiO}_{2}$ than NASC and UCC. In the case of trace elements, $83.5 \%$ samples have higher values than PASS in the case of $\mathrm{Y}$, whereas $\mathrm{Sr}$ and $\mathrm{Th}$ are higher in $33.5 \%$ and $21.5 \%$ of the samples than NASC. The detailed results are given in table 3. Furthermore, comparative analysis also indicated that the first group of elements has near to similar values as those of crustal averages, whereas the second group of elements has values 1-5 times enriched in comparison with the crustal average values. Overall, these observations suggest that in the case of a significant number of samples, the ferromagnesian minerals are affected by the modifications during weathering processes.

To further understand the coherence of the elements, the correlation matrix (CM) of major oxides (wt\%) and trace elements (ppm) has been carried out as given in table 4 . The $\mathrm{CM}$ gives the value of CORREL (or PEARSON) coefficient applied to each possible pair of measurement variables and reveals the degree of linear correlation between two variables. The $\mathrm{CM}$ clearly demonstrates that $\mathrm{SiO}_{2}, \mathrm{Al}_{2} \mathrm{O}_{3}, \mathrm{TiO}_{2}, \mathrm{Fe}_{2} \mathrm{O}_{3}$, $\mathrm{MnO}, \mathrm{K}_{2} \mathrm{O}$, Th and $\mathrm{Y}$ are positively correlated with each other and negatively correlated with $\mathrm{CaO}, \mathrm{MgO}$ and $\mathrm{Sr}$ and vice versa. The positive or

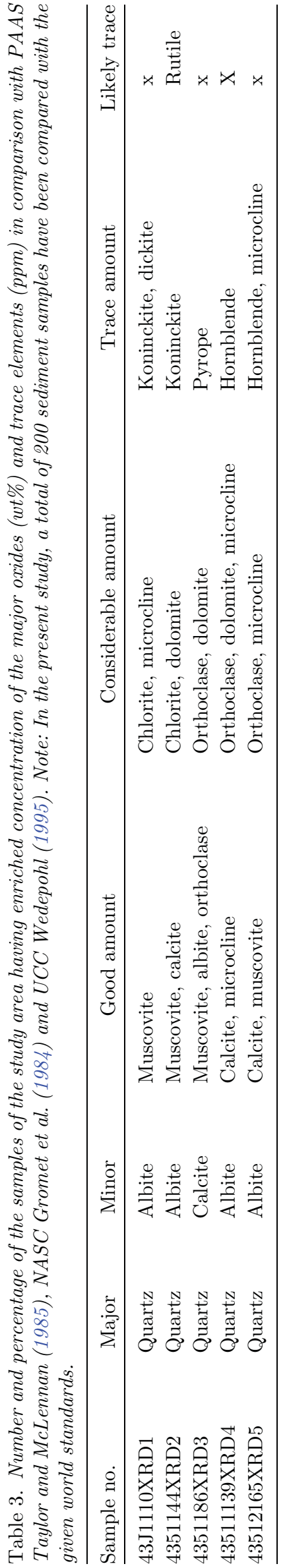


Table 4. CM of major oxides (wt\%) and trace elements (ppm) of sediment samples of the study area. Note: The significant values are presented in bold font.

\begin{tabular}{|c|c|c|c|c|c|c|c|c|c|c|c|}
\hline Element & $\mathrm{SiO}_{2}$ & $\mathrm{Al}_{2} \mathrm{O}_{3}$ & $\mathrm{Fe}_{2} \mathrm{O}_{3}$ & $\mathrm{CaO}$ & $\mathrm{MgO}$ & $\mathrm{K}_{2} \mathrm{O}$ & $\mathrm{MnO}$ & $\mathrm{TiO}_{2}$ & $\mathrm{Sr}$ & Th & $\mathrm{Y}$ \\
\hline $\mathrm{SiO}_{2}$ & 1.00 & & & & & & & & & & \\
\hline $\mathrm{Al}_{2} \mathrm{O}_{3}$ & 0.60 & 1.00 & & & & & & & & & \\
\hline $\mathrm{Fe}_{2} \mathrm{O}_{3}$ & 0.27 & 0.80 & 1.00 & & & & & & & & \\
\hline $\mathrm{CaO}$ & -0.96 & -0.76 & -0.47 & 1.00 & & & & & & & \\
\hline $\mathrm{MgO}$ & -0.80 & -0.52 & -0.14 & 0.79 & 1.00 & & & & & & \\
\hline $\mathrm{K}_{2} \mathrm{O}$ & 0.38 & 0.36 & -0.02 & -0.40 & -0.64 & 1.00 & & & & & \\
\hline $\mathrm{MnO}$ & 0.27 & 0.51 & 0.63 & -0.41 & -0.24 & 0.08 & 1.00 & & & & \\
\hline $\mathrm{TiO}_{2}$ & 0.61 & 0.75 & 0.78 & -0.73 & -0.46 & -0.02 & 0.61 & 1.00 & & & \\
\hline $\mathrm{Sr}$ & -0.82 & -0.81 & -0.52 & 0.89 & 0.85 & -0.56 & -0.46 & -0.70 & 1.00 & & \\
\hline Th & 0.56 & 0.56 & 0.31 & -0.52 & -0.50 & 0.37 & 0.15 & 0.42 & -0.57 & 1.00 & \\
\hline $\mathrm{Y}$ & 0.86 & 0.71 & 0.45 & -0.91 & -0.67 & 0.29 & 0.44 & 0.72 & -0.78 & 0.53 & 1.00 \\
\hline
\end{tabular}

negative correlation and coherence of these elements was attributed to the same source from geogenic contribution. The CM indicated the possibility of two provenances or source rocks of these elements dominantly exposed in the area. The elemental distribution overall reveals higher values towards the north-northeastern areas to the southeastern areas and correlates significantly with the hard rock geology consisting mainly of the Panjal volcanics and Triassic limestones that are the basic and carbonate rocks of the area. The coherence and positive correlation among the $\mathrm{SiO}_{2}, \mathrm{Al}_{2} \mathrm{O}_{3}, \mathrm{TiO}_{2}, \mathrm{Fe}_{2} \mathrm{O}_{3}, \mathrm{MnO}, \mathrm{K}_{2} \mathrm{O}$, Th and $\mathrm{Y}$ indicate that these elements may have been derived from andesite and basaltic volcanics of the area. Acid rocks usually contain more thorium (Th) than mafic rocks, and in sediments, it is likely to be more concentrated in argillaceous deposits. The carrier of Th is mainly monazite mineral which is very resistant to weathering thus enriching weathered deposits in $\mathrm{Th}$ content (Govindaraju 1994). The occurrence of yttrium (Y) in the Earth's crust is relatively common. Basic rocks contain somewhat higher amounts of Y than ultramafic rocks (Ure and Bacon 1978). Similarly, higher $\mathrm{CaO}, \mathrm{Mgo}$ and $\mathrm{Sr}$ values observed in the sediments of the south-eastern parts of the study area are attributed to the input from the adjacent limestone-dolomite terrain that contributes carbonate-rich sediments to the area (Jonathan et al. 2004). It has been established that the biogeochemical characteristics of $\mathrm{Sr}$ are similar to those of $\mathrm{Ca}$ and $\mathrm{Mg}$. However, it is also notable that $\mathrm{Sr}$ is very often associated with $\mathrm{Ca}$, and, to a lesser extent, with $\mathrm{Mg}$ in the terrestrial environment (Govindaraju 1994).
To further understand the source of elements, the variation diagrams of selected volcanic and carbonate rocks representing major oxides (wt\%) and trace elements (ppm) are plotted against $\mathrm{Al}_{2} \mathrm{O}_{3}$ (figure 4). $\mathrm{Al}_{2} \mathrm{O}_{3}$ shows a positive trend with $\mathrm{TiO}_{2}$, $\mathrm{Fe}_{2} \mathrm{O}_{3}$, Th and $\mathrm{Y}$ and an inverse trend with Cao, $\mathrm{MgO}$ and $\mathrm{Sr}$, thereby indicating the volcanic source for the first group of elements and the carbonate source for the second group of elements. The $\mathrm{Al}_{2} \mathrm{O}_{3} /$ $\mathrm{TiO}_{2}$ ratio is also used to track the provenance of the source rock material (Armstrong-Altrin et al. 2014). The $\mathrm{Al}$ in igneous rocks mostly exists in feldspars and Ti exists in olivine, pyroxene, hornblende, biotite and ilmenite that are mostly mafic minerals. The previous studies have reported $\mathrm{Al}_{2} \mathrm{O}_{3} / \mathrm{TiO}_{2}$ ratios in mafic igneous rocks between 3 and 8 , whereas in intermediate igneous rocks, it is reported to be between 8 and 21 and between 21 and 70 in felsic igneous rocks (Hayashi et al. 1997). In the present study, the $\mathrm{Al}_{2} \mathrm{O}_{3} / \mathrm{TiO}_{2}$ ratio of the sediments varied from 10.25 to 31.18 , indicating provenance and weathering of an intermediate to felsic igneous source rocks. However, it is important to note that the samples that contain an element many times higher than the mean value for the samples are considered as anomalous (Eberl and Smith 2009). In this study, Cao (wt\%), Mgo (wt\%) and $\mathrm{Sr}(\mathrm{ppm})$ in the south-eastern parts of the study area are 1 to 5 times enriched than mean values. The dominant lithologies in the study area are Panjal volcanics and carbonate rocks. Thus, the higher content of Cao (wt\%), Mgo (wt\%) and Sr (ppm) in surface sediments in this part of the area is attributed mainly to the carbonate provenance and is also considered a major contributor for these high anomalous values than the volcanic source rocks. 

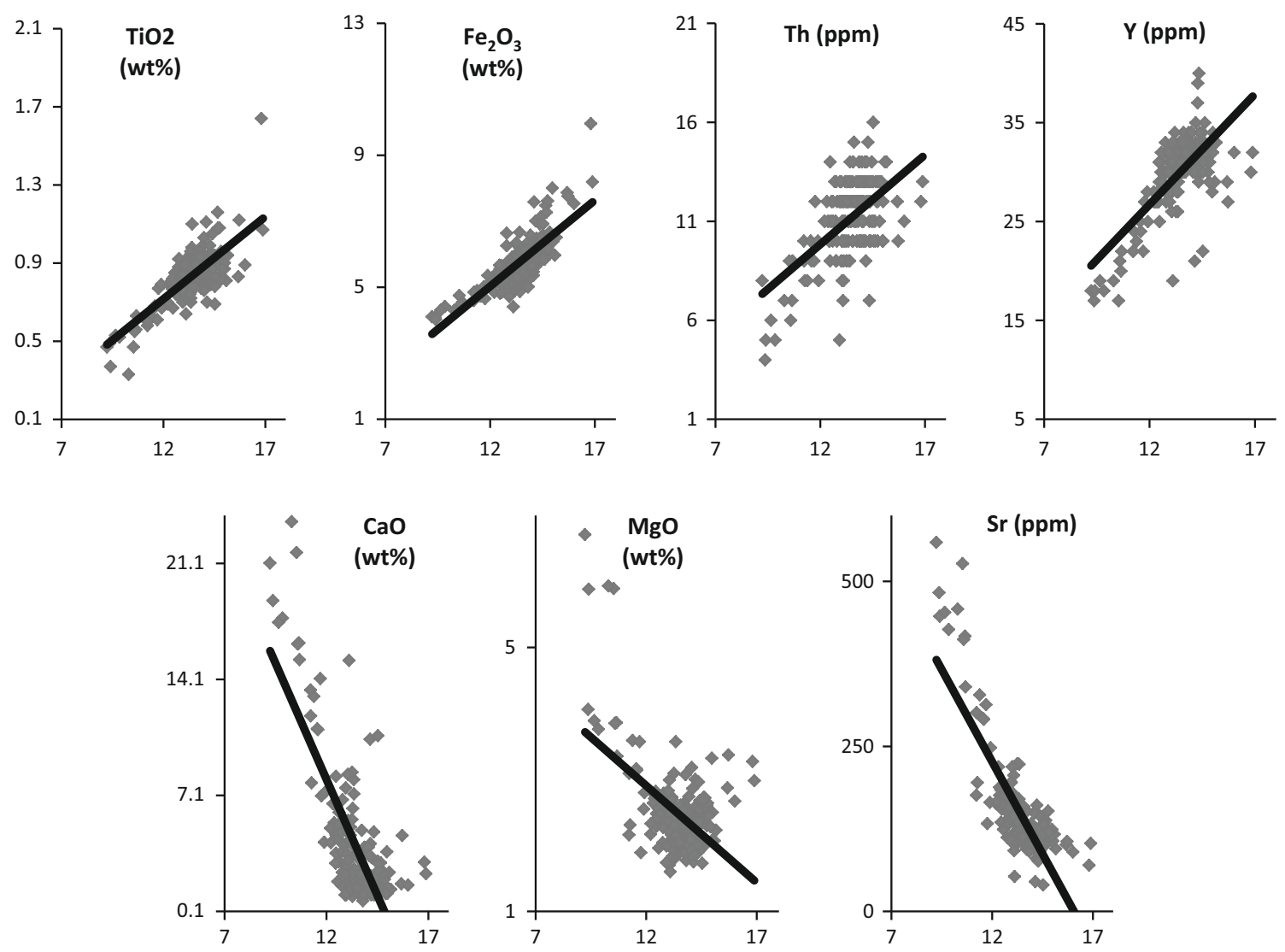

Figure 4. Variation diagrams of bulk sediment geochemical data of $\mathrm{Al}_{2} \mathrm{O}_{3} \%$ plotted on the $x$-axis and its correlation with selected few major oxides (wt\%) and trace elements (ppm) plotted on the $y$-axis in the study area.

\subsection{Mineral distribution trends}

The Himalayan mountain range is characterised by the mechanical erosional rates averaging $>1$ $\mathrm{mm} \mathrm{yr}^{-1}$. These erosion rates far exceed those rates at which rocks are converted to soils through chemical and physical weathering (Raymo et al. 1988). However, due to the rapid mechanical denudations of the rocks in the Himalayas, the maturity of the sediments remains poor as the soilrelated processes are very slow (Burbank et al. 1996). The sediments of the KB which are fluvial-glacial sediments flushed from all sides of mountain flanks may be an exception to the immaturity of Himalayan sediments. In the present study, mineralogical studies of the sediment samples showed that quartz is the major constituent mineral followed by muscovite. However, the calcite and K-feldspar minerals are present in good amount; albite and calcite occur as minor minerals; chlorite, microcline, orthoclase and dolomite are present in considerable amount and koninckite, dicktite, pyrope, hornblende, microcline and rutile are present in traces. Overall, these minerals identified in the sediments also indicate basic/ volcanic and carbonate rocks as the dominant source of the sediments. The mineralogical results of the sediment samples are given in table 3. Furthermore, the mineral composition of the sediments can also have an effect on the elemental concentration. In the sediments of the study area, quartz represents more than $58.66 \%$ of the detrital minerals followed by other detrital materials representing oxides of $\mathrm{Al}_{2} \mathrm{O}_{3}, \mathrm{TiO}_{2}, \mathrm{Fe}_{2} \mathrm{O}_{3}, \mathrm{MnO}$ and $\mathrm{K}_{2} \mathrm{O}$. Aluminium mostly resides in alumina silicates, which is the most important carrier of absorbed metals (Jonathan et al. 2004).

\subsection{Weathering pattern trends}

Elemental data are used as a proxy to understand the mineralogy of sediments, provenance and weathering patterns. For example, in the case of the least-weathered rocks, there is not much variation in the major and trace element content of the derived sediments. To derive the weathering of the source rocks from elemental data, ternary diagrams developed by Nesbitt and Young (1982) and Nesbitt et al. (1996) have been frequently used. The 


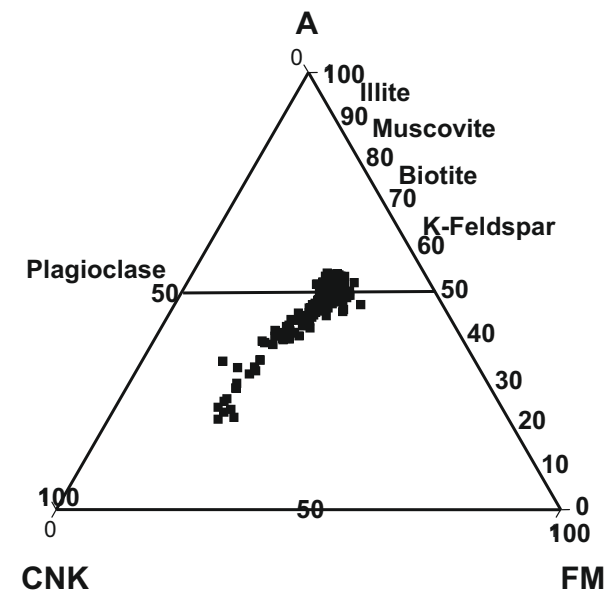

(a)

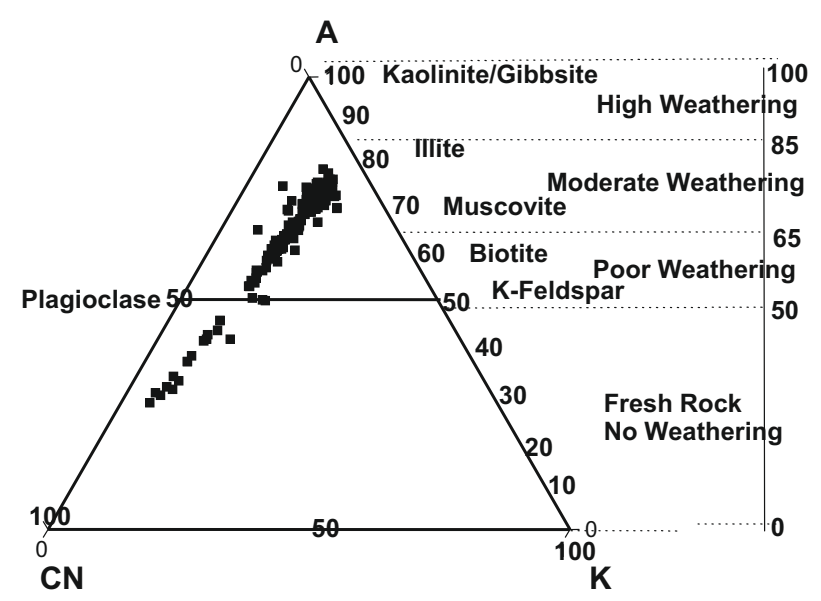

(b)

Figure 5. Triangular plots: (a) A-CNK-FM and (b) A-CN-K (after Nesbitt and Young 1982, 1984) showing the chemical index of alteration (CIA) and weathering intensity in the study area.

ternary diagrams such as A-CN-K with $\mathrm{Al}_{2} \mathrm{O}_{3}-\left(\mathrm{CaO}+\mathrm{Na}_{2} \mathrm{O}\right)-\mathrm{K}_{2} \mathrm{O}$ and $\mathrm{A}-\mathrm{CNK}-\mathrm{FM}$ with $\mathrm{Fe}_{2} \mathrm{O}_{3}+\mathrm{MgO}-\left(\mathrm{CaO}+\mathrm{Na}_{2} \mathrm{O}+\mathrm{K}_{2} \mathrm{O}\right)-\mathrm{Al}_{2} \mathrm{O}_{3}$ consist of three axes to deduce weathering trends. In the present study, the ternary diagrams were also used to understand the weathering patterns as shown in figure $5 \mathrm{a}$ and $\mathrm{b}$. As observed, both the ternary diagrams plotted the values of $\mathrm{Al}_{2} \mathrm{O}_{3}, \mathrm{CaO}, \mathrm{Na}_{2} \mathrm{O}$, $\mathrm{K}_{2} \mathrm{O}$ and $\mathrm{M}_{2} \mathrm{O}$ very similar to that of the crustal average (Taylor and McLennan 1985), thereby reflecting a very poor weathering pattern in the area. The plots also indicated that the weathering has not reached a stage at which significant amounts of the alkali and alkaline earth elements will be removed from the sediments. These results are further substantiated by the identification of albite minerals in the sediment samples (table 2). The presence of albite minerals also indicated that the sediments are not mature enough in the study area.

Moreover, to determine the degree of weathering, two indices such as the chemical index of alteration (CIA) and chemical index of weathering (CIW) have been used in this study. The weathering indices essentially measure the degree of depletion of mobile components relative to immobile components during weathering. An equation of CIA proposed by Nesbitt and Young (1982) for calculating the degree of weathering is given as

$$
\begin{aligned}
\mathrm{CIA}= & \mathrm{Al}_{2} \mathrm{O}_{3} /\left(\mathrm{Al}_{2} \mathrm{O}_{3}+\mathrm{CaO}^{*}+\mathrm{Na}_{2} \mathrm{O}+\mathrm{K}_{2} \mathrm{O}\right) \\
& \times 100
\end{aligned}
$$

where $\mathrm{CaO}^{*}$ is the amount of $\mathrm{CaO}$ incorporated into the silicate fraction of the rock. As reported previously, the CIA value for diopside is 0 ; fresh basalt has values between 30 and 45; fresh albite, anorthite and K-feldspar have a value of 50 ; granites and granodiorites have values between 45 and 55; muscovite has a value of 75 ; illite and montmorillonites have a value between 75 and 85 and chlorite and kaolinite have a value near 100 . However, it is important to note that for the carbonate and apatite content, a correction is made. Following the procedure of Nesbitt and Young (1982), the correction of the amount of $\mathrm{CaO}$ incorporated in the silicate fraction of the rock of the present study area has been carried out, and accordingly, the CIA has been derived. The CIA value of sediments in the present study varied from 26.4 to 77.8 with a mean of 65.3 (figure $6 \mathrm{a}$ ). The derived CIA values are almost close to those of PAAS, UCC and NASC.

In addition, Harnois (1988) has proposed a simplified equation for calculating the CIW. This equation in comparison with CIA does not include $\mathrm{K}_{2} \mathrm{O}$ into the account. Therefore, this equation is also known as $\mathrm{K}_{2} \mathrm{O}$-free CIA. However, it is important to mention that the CIW index increases with the degree of depletion of the sediment in $\mathrm{Na}$ and $\mathrm{Ca}$ relative to $\mathrm{A} 1$. The equation of CIW is given below as

$$
\mathrm{CIW}=\mathrm{Al}_{2} \mathrm{O}_{3} /\left(\mathrm{Al}_{2} \mathrm{O}_{3}+\mathrm{CaO}+\mathrm{Na}_{2} \mathrm{O}\right) \times 100 .
$$

The CIW value of sediments of the present study varied from 27.3 to 87.8 with a mean of 74.2 (figure 6b).

The optimum fresh value for CIA and CIW is $\leq 50$ and the optimum weathered value for CIA and 


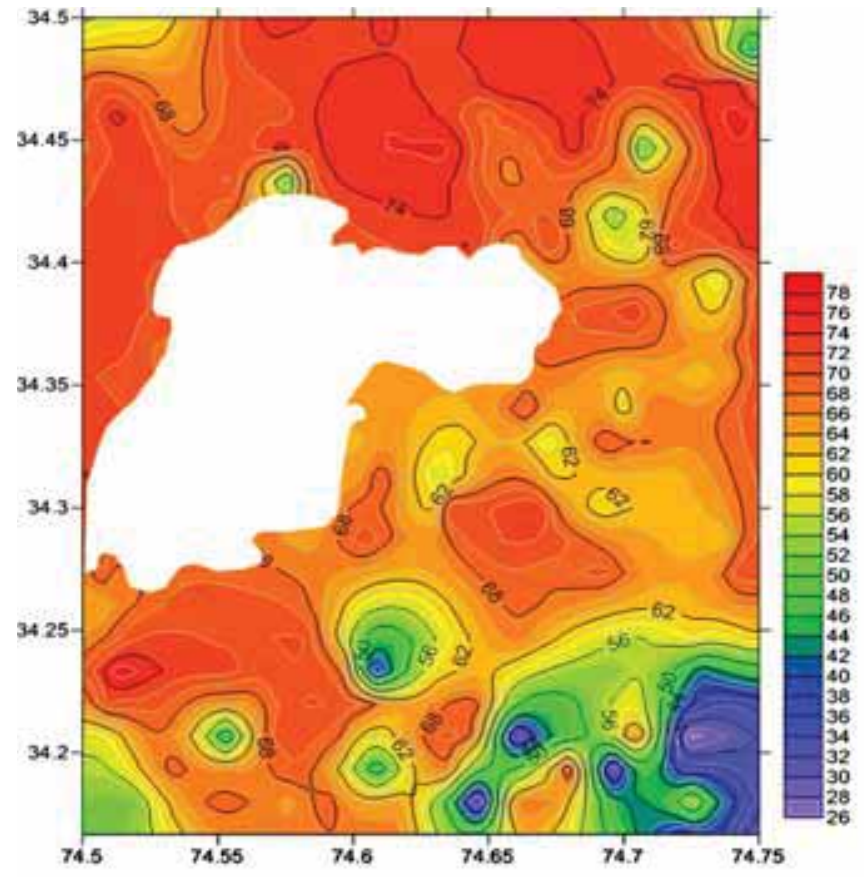

(a)

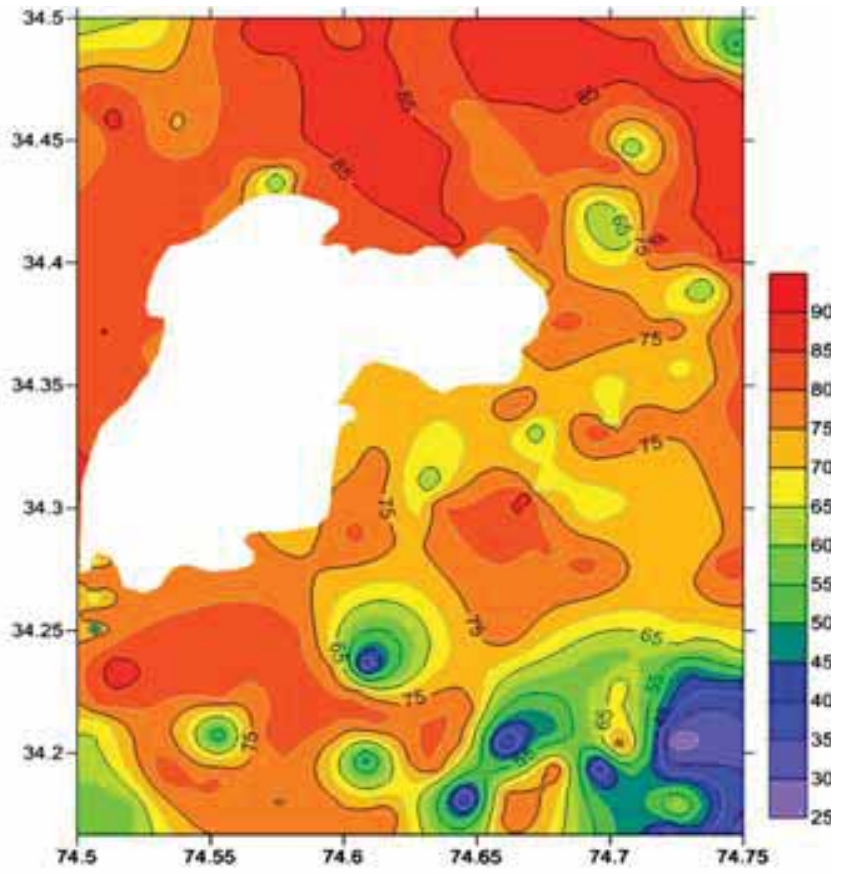

(b)

Figure 6. Distribution pattern of the (a) CIA and (b) CIW in the study area.

CIW is 100. Both indices do not allow Al mobility and show a positive trend of the index up-profile with an increase in weathering. CIA and CIW are essentially a measure of the extent of conversion of feldspars to clay minerals (Nesbitt and Young 1984; Maynard et al. 1995). In this study, both the indices were found to be lower than those of average shale, thereby indicating that the degree of weathering in the area is poor to moderate. This low to moderate weathering may be because of the nearness of the provenance of the derived sediments vis-à-vis least transportation and mechanical weathering. Although the hydroclimatic conditions in this area are able to carry the mechanical disintegration of the source rock material, due to the short distance of sediment transportation from source rocks, the maturity of sediments has not been achieved. This process is very well reflected by the presence of fresh albite in sediments and the absence of CIA values greater than 78 which are usually the values exhibited by mature clay minerals. Overall, the low to moderate values of both the indices reflected the absence of clay minerals and the presence of detrital feldspars which is also evident from the $\mathrm{A}-\mathrm{CN}-\mathrm{K}$ and A-CNK-FM diagrams (figure $5 \mathrm{a}$ and $\mathrm{b}$ ). From the analysis, the south-eastern part of the study area is least weathered in comparison with the rest of the study area. This observation matches very well with the distribution of carbonate rock representing elements and matches poorly with elements representing volcanic terrain.

\section{Conclusion}

In this study, a high-density sediment sampling was carried out in parts of Bandipora-Ganderbal districts of the KB to understand the spatial distribution patterns of surface sediment geochemistry, its provenance and degree of weathering of the source rock material. The sampling was carried out as per the approved SOP (2014) of GSI in toposheet No. 43J/11 and J/12 (part) covering an area of $800 \mathrm{~km}^{2}$. About 200 stream and slope sediment samples on a 2:2 grid pattern were collected for major oxide and trace element analysis followed by the collection of five sediment samples randomly for mineralogical and/or XRD studies. The analysis included the generation of elemental distribution maps, $\mathrm{CM}$ and variation diagrams, mineralogical studies and calculation of weathering indices.

The elemental distribution maps indicated a similarity in spatial distribution with generally higher concentrations around the northeastern and southeastern areas where it significantly coincides with the local geology of the area. The analysis 
indicated two provenances or source rock materials that control the geochemistry of the sediments in this area. For instance, $\mathrm{SiO}_{2}, \mathrm{Al}_{2} \mathrm{O}_{3}, \mathrm{TiO}_{2}, \mathrm{Fe}_{2} \mathrm{O}_{3}$, $\mathrm{MnO}, \mathrm{K}_{2} \mathrm{O}$, Th and $\mathrm{Y}$ are positively correlated and formed the first coherent group of elements whose geochemistry is controlled dominantly by the basic volcanic rocks exposed extensively in the area. However, the elements such as $\mathrm{CaO}, \mathrm{MgO}$ and $\mathrm{Sr}$ formed the second coherent group whose geochemistry is controlled dominantly by the carbonate lithology such as limestone and dolomites of the area. These results are also substantiated by the mineralogical nature of the sediments.

Furthermore, the A-CN-K and A-CNK-FM plots indicated low to moderate weathering in this area. The weathering indices CIA and CIW also revealed low (27) to moderate (78) weathering patterns. This observation is very well reflected by the presence of fresh albite in sediments and the absence of CIA values greater than 78 that is usually reflected by the highly weathered clay minerals. The south-eastern areas are observed to be less weathered in comparison with other parts of the study area.

\section{Acknowledgements}

The authors are thankful to the director general, the Geological Survey of India for formulating the NGCM programme, for providing the financial support to carry out field work and laboratory facilities for geochemical date generation. Thanks are due to the Deputy Director General, State Unit, J\&K, Jammu/Srinagar for providing logistic support without which the work may have not been completed. The authors express their sincere thanks to the reviewers for their constructive suggestions and comments that helped improve the manuscript.

\section{References}

Agarwal K K and Agarwal G K 2005 Sandbox analogue model an example from the Karewa basin, Kashmir Himalayas India; Int. J. Earth Sci. 94 47-52.

Armstrong-Altrin J S, Nagarajan R, Lee Yong I L, KasperZubillaga Juan J and Córdoba-Saldaña Leslie P 2014 Geochemistry of sands along the San Nicolás and San Carlos beaches, Gulf of California, Mexico: Implication for provenance; Turk. J. Earth Sci. 23 533-558.

Babeesh C, Lone A and Achyuthan H 2017 Geochemistry of Manasbal Lake sediments, Kashmir: Weathering, provenance and tectonic setting; J. Geol. Soc. India 89 563-572.
Bhat A A and Bhat N A 2014 Report on geochemical mapping of Kashmir nappe and Karewa group of rocks covering parts of Anantnag, Baramulla and Srinagar Districts, Jammu \& Kashmir in toposheet no. 43K13 and 14, Geological Survey of India, Operation: J\&K, NR, Field Season 2013-2014.

Bhatt D K and Chatterji A K 1976 An appraisal of field observations on the geology of the Plio-Pleistocene Karewa Group and more recent Quaternary deposits of Kashmir Valley; In: Proceedings of VI Indian Colloq. Micropaleont. Stratigrap., pp. 11-21.

Burbank D W and Johnson G D 1982 Intermontane basin development in the past $4 \mathrm{Myr}$ in the northeast Himalaya; Nature 298 432-436.

Burbank D, Leland J, Fielding E, Anderson R, Brozovic N, Reid M and Duncan C 1996 Bedrock incision, rock uplift and threshold hill slopes in the north-western Himalayas; Nature 379 505-510.

Cohen D R, Silva-Santisteban C M, Rutherford N F, Garnett D L and Waldron H M 1999 Comparison of bio-geochemical and stream sediment geochemical patterns in the north eastern region of SW; J. Geochem. Explor. 66 469-489.

Dar R A, Chandra R and Romshoo S A 2013 Morphotectonic and lithostratigraphic analysis of intermontane Karewa Basin of Kashmir Himalayas, India; J. Mt. Sci. 10 1-15.

Darnley A G, Björklund A, Bølviken B, Gustavsson N, Koval P V and Plant J A 1995 A global geochemical database for environmental and resource management: Recommendations for international geochemical mapping; IGCP Proj. 259. UNESCO Publ.

Das A, Krishnaswami S, Sarin M M and Pande K 2005 Chemical weathering in the Krishna Basin and Western Ghats of the Deccan Traps, India: Rates of basalt weathering and their controls; Geochim. Cosmochim. Acta $\mathbf{6 9}(\mathbf{8})$ 2067-2084.

De Terra H and Paterson T T 1939 Studies on the Ice Age in India and associated human cultures; Carnegie Inst., Washington, DC 493 1-354.

De Vos W and Tarvainen T 2006 Geochemical atlas of Europe part 2 interpretation of geochemical maps, additional tables, figures, maps, and related publications; Geol. Surv. Finland.

Eberl D D and Smith David B 2009 Mineralogy of soils from two continental scale transects across the United States and Canada and its relation to soil geochemistry and climate; Appl. Geochem. 24 1394-1404.

Fralick P W and Kronberg B I 1997 Geochemical discrimination of clastic sedimentary rock from major element chemistry of lutites; Nature 299 715-717.

Garrett R G, Reimann C, Smith D B and Xie X 2008 From geochemical prospecting to international geochemical mapping: An historical overview; Geochem.: Explor. Environ. Anal. 8 205-217.

Govindaraju K 1994 Compilation of working values and sample description for 383 geostandards; Geostand. Newsl. 181.

Gromet L P, Dymek R F, Haskin L A and Korotev R L 1984 The 'North American shale composite': Its compilation, major and trace element characteristics; Geochim. Cosmochim. Acta 48 2469-2482.

Grunsky E C, Drew L J, David M and Sutphin D M 2009 Process recognition in multi element soil and stream sediment geochemical data; Appl. Geochem. 24 1602-1616. 
Harnois L 1988 The CIW index: A new chemical index of weathering; Sediment. Geol. 55 319-322.

Hayashi K I, Fujisawa H, Holland H D and Ohmoto H 1997 Geochemistry of $1.9 \mathrm{Ga}$ sedimentary rocks from northeastern Labrador, Canada; Geochim. Cosmochim. Acta 61 4115-4137.

Johnson C C, Breward N, Ander E L and Ault L 2005 G-BASE: Baseline geochemical mapping of Great Britain and northern Ireland; Geochem.: Explor. Environ. Anal. 5 $347-357$.

Jonathan M P, Ram Mohan V and Srinivasalu S 2004 Geochemical variations of major and trace elements in recent sediments, off the Gulf of Mannar, the southeastcoast of India; Environ. Geol. 45 466-480.

Kapoor H M 1963 A note on the geochemical study of the stream sediments from Liddar river, Anantnag District Jammu \& Kashmir State; Geological Survey of India, Operation: J\&K, NR, Field Season 1962-1963.

Martin J M and Meybeck M 1979 Elemental mass-balance of material carried by major world rivers; Mar. Chem. 7 $173-206$

Maynard J B, Sutton S J, Robb L J, Ferraz M F and Meyer F M 1995 A paleosol developed on hydrothermally altered granite from the hinterland of the Witwatersrand basin: Characteristics of a source of basin fill; J. Geol. 103 357-377.

McLennan S M, Hemming S, McDaniel D K and Hanson G N 1993 Geochemical approaches to sedimentation, provenance, and tectonics; Geol. Soc. Am. Spec. Paper 284 $21-40$.

Mir R A and Jeelani G 2015 Textural characteristics of sediments and weathering in the Jhelum River basin located in Kashmir Valley, western Himalaya; J. Geol. Soc. India 86 445-458.

Mir R A 2018 Recent changes of two parts of Kolahoi Glacier and its controlling factors in Kashmir basin, western Himalaya; Remote Sens. Appl. Soc. Environ. 11 265-281.

Mir R A, Jeelani G and Dar F A 2016 Spatio-temporal patterns and factors controlling the hydrogeochemistry of the river Jhelum basin, Kashmir Himalaya; Environ. Monit. Assess. 188(7) 438.

Nesbitt H W 1979 Mobility and fractionation of REE during weathering of granodiorite; Nature 279 206-210.

Nesbitt H W and Young G M 1982 Early proterozoic climates and plate motions inferred from major element chemistry of lutites; Nature 299 715-717.

Nesbitt H W and Young G M 1984 Prediction of some weathering trends of plutonic and volcanic rocks based on thermodynamic and kinetic considerations; Geochim. Cosmochim. Acta 48 1523-1534.

Nesbitt H W, Young G M, McLennan S M and Keays R R 1996 Effects of chemical weathering and sorting on the petrogenesis of siliciclastic sediments, with implications for provenance studies; J. Geol. 104 525-542.

Oliver M A 1997 Soil and human health - A review; Eur. J. Soil Sci. 48(4) 73-592.

Piper D Z, Ludington S, Duval J S and Taylor H E 2006 Geochemistry of bed and suspended sediment in the Mississippi River system: Provenance versus weathering and winnowing; Sci. Total Environ. 362 179-204.

Pratt C and Lottermoser B G 2007 Mobilisation of traffic derived trace metals from road corridors into coastal stream and estuarine sediments, Cairns, northern Australia; Environ. Geol. 52 437-448.

Rajamani V, Tripathi J K and Malviya V P 2009 Weathering of lower crustal rocks in the Kaveri river catchment, southern India: Implications to sediment geochemistry; Chem. Geol. 265 410-419.

Ranasinghe P N, Fernando G W A R, Dissanayake C B and Rupasinghe M S 2008 Stream sediment geochemistry of the Upper Mahaweli River Basin of Sri Lanka - geological and environmental significance; J. Geochem. Explor. 99 1-28.

Rashid A S, Ather M and Farid A K 2013 Sediment water interaction at higher altitudes: Example from the geochemistry of Wular Lake sediments, Kashmir Valley, northern India; Procedia Earth Planet. Sci. 7 786-789.

Rashid S A, Ganai J A, Masoodi A and Khan F A 2015 Major and trace element geochemistry of lake sediments, India: Implications for weathering and climate control; Arabian J. Geosci. 8 5677-5684.

Raymo M E, Ruddiman W F and Froelich P N 1988 Influence of late cenozoic mountain building on ocean geochemical cycles; Geology 16 649-653.

Razdan M L and Raina C B 1986 Report on the geological mapping of the granitoids of Kazinag and Dudran, Baramulla District and traverse studies of Hanti granitoids (Gurais area), Baramulla District for sulphide mineralisation; Geological Survey of India, Operation: J\&K, NR, Field Season 1985-1986.

Reimann C and Garrett R G 2005 Geochemical background: Concept and reality; Sci. Total Environ. 50 12-27.

Salminen R, Batista M J, Bidovec M, Demetriades A, De Vivo $\mathrm{B}$ and De Vos W 2005 FOREGS geochemical atlas of Europe. Part 1: Background information methodology and maps; Geol. Surv. Finland.

Sarah S, Jeelani G and Ahmed S 2011 Assessing variability of water quality in a groundwater fed perennial lake of Kashmir Himalayas using linear geostatistics; J. Earth Syst. Sci. 120(3) 399-411.

Shah R A, Achyutha H, Lon A M and Ramanibai R 2017 Diatoms, spatial distribution and physicochemical characteristics of the Wular lake sediments, Kashmir valley, Jammu and Kashmir; J. Geol. Soc. India 90 159-168.

Sharma A and Rajamani V 2001 Weathering of charnockites and sediment production in the catchment area of the Cauvery River, southern India; Sedim. Geol. 143 169-184.

Singh I 1982 Report on petrological, volcanological and stratigraphical studies of Panjal Volcanics in Liddar and Sind valleys and Bandipora area, Anantnag, Srinagar and Baramulla districts, Jammu \& Kashmir State; Geological Survey of India, Operation: J\&K, NR, Field Season 1981-1982.

Smith D B 2009 Geochemical studies of North American soils: Results from the pilot study phase of the North American soil geochemical landscapes project; Appl. Geochem. 24 $1355-1356$.

Standard Operation Procedure (SOP) 2014 Standard operating procedure for National geochemical mapping \& quality management Revised \& updated May, 2014, Mission-I: Baseline Geosciences Data Generation.

Tan J 1989 The atlas of endemic diseases and their environments in the people's republic of China; Science Press, Beijing. 
Taylor S R and McLennan S M 1985 The continental crust: Its composition and evolution; Blackwell, Oxford, London.

Thakur V C and Rawat B S 1992 Geological map of the Western Himalaya; Survey of India.

Tripathi J K, Ghazanfari P, Rajamani V and Tandon S K 2007 Geochemistry of sediments of the Ganges alluvial plains: Evidence of large-scale sediment recycling; Quat. Int. 159 $119-130$.

Ure A M and Bacon J R 1978 Comprehensive analysis of soils and rocks by spark-source mass Spectrometry; Analyst 103807.

Wadia D N 1931 The syntaxis of NW Himalaya, its rocks, tectonics and orogeny; Rec. Geol. Surv. India 65 189-220.
Wang X, Chi Q, Liu H, Nie L and Zhang B 2007 Wide-spaced sampling for delineation of geochemical provinces in desert terrains, northwestern China; Geochem.: Explor. Environ. Anal. 7 153-161.

Wedepohl H K 1995 The composition of the continental crust; Geochim. Cosmochim. Acta 59 1217-1232.

Weltje G J and von Eynatten H 2004 Quantitative provenance analysis of sediments: Review and outlook; Sedim. Geol. 171 1-11.

Xie X and Cheng H 1997 The suitability of floodplain sediment as a global sampling medium: Evidence from China; $J$. Geochem. Explor. 58 51-62

Corresponding editor: Pulak Sengupta 